The BDJ News section accepts items that include general news, latest research and diary events that interest our readers. Press releases or articles may be edited, and should include a colour photograph if possible. Please direct your correspondence to the News Editor, Arveen Bajaj at the BDJ, The Macmillan Building, 4 Crinan Street, London N19XW or by email to bdj@bda.org

\section{New Honorary Professor at Glasgow}

Dr Jim McDonald, Consultant Orthodontist and Dean of the Dental Faculty of the Royal College of Surgeons of Edinburgh, has been appointed an Honorary Professorship in Orthodontics at the University of Glasgow. Professor McDonald is a prominent figure in orthodontics with a strong track record in postgraduate education and has been involved in much international collaboration. His research interests are in the fields of craniofacial development and airway control, complementing the research strategy of the Biotechnology and Craniofacial Sciences Research Group at Glasgow Dental School.

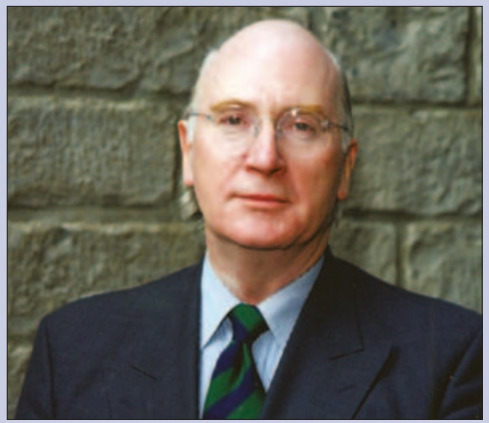

\section{Visiting Professor appointed}

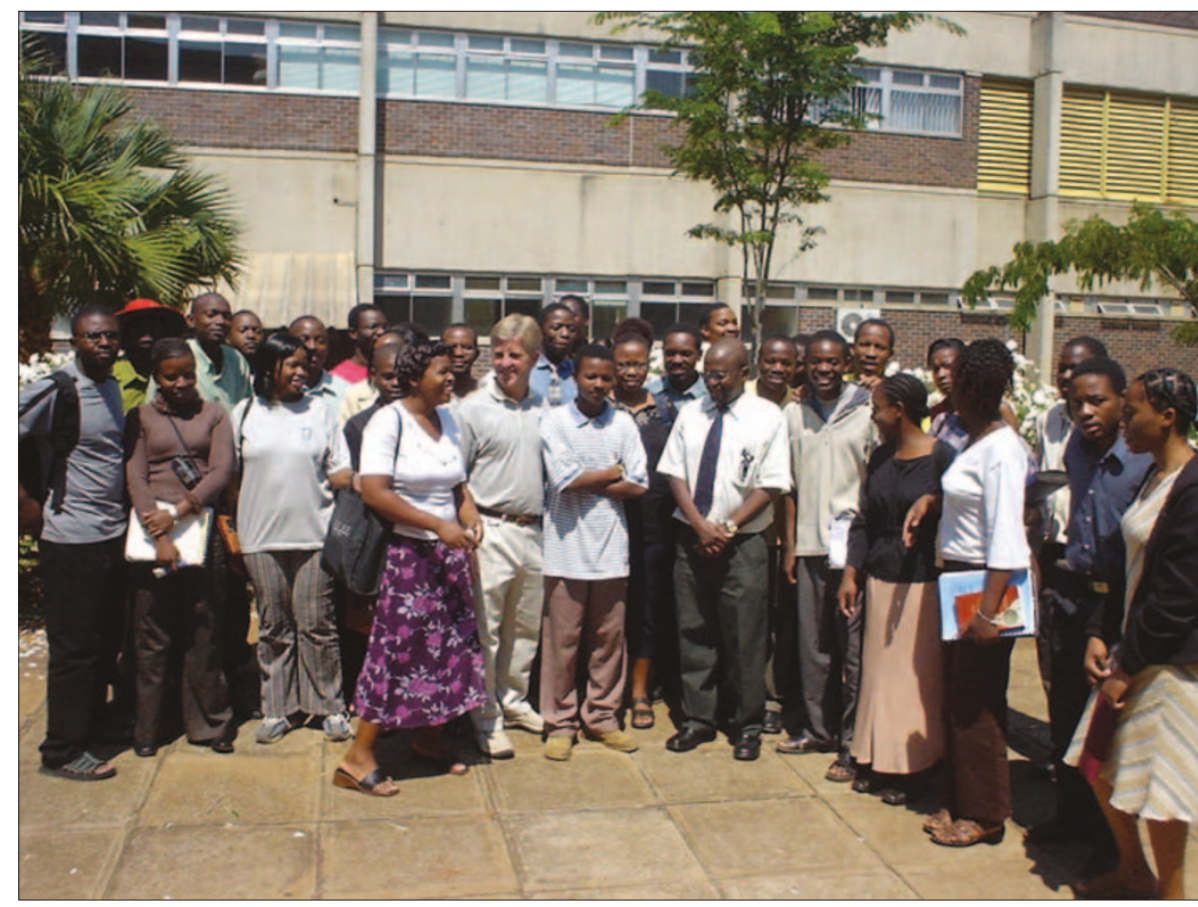

Dr. Hendrik de Waal, a specialist in periodontics from Solihull, has been appointed Visiting Professor for Periodontics at the Zimbabwe University Dental School in Harare. He was born and raised in Zimbabwe and is seen here (centre of picture) with the 2005 final and fifth year BDS students and Professor Chidzonga (Dean of Dental School), during a recent visit. Anyone interested in supporting the students with second hand dental instruments, equipment or clothing is welcome to contact his practice on Tel/Fax 01564-771703 or email hendrikdewaal@aol.com. For more information visit www.specialistperiodontics.co.uk.

\title{
Caribbean contribution to the NHS to be acknowledged
}

A major new book acknowledging the invaluable contribution made by people from the Caribbean Commonwealth in the formative years of the NHS is to be launched in October this year. The project from the Department of Health is set to coincide with Black History Month in the UK and will document and celebrate the work and commitment of the people from the Caribbean who helped set the foundations for today's NHS health service, during its formative years between 1948 and 1969.

NHS staff were actively recruited from the Caribbean by the British government to help build the newly formed NHS, at a time when the UK faced severe shortages in labour at all levels in the health service, which included a shortage of 54,000 nurses in 1949. Recruitment came through advertisements in local Caribbean newspapers and active recruitment drives in the colonies. Many recruits travelled to the UK by boat or plane (usually paid for by friends or relatives rather than the government) to take up positions in hospitals across the country. The full range of occupations will be depicted including dentistry as well as those who worked at all levels of the NHS. Anyone from the Caribbean who worked in the NHS Dental Service during that period and who would be prepared to be interviewed, either in person or over the telephone, please contact Julia Campion, Commonwealth Dental Association by email at juliacampion@cdauk.com, or telephone +44 (0)20 7229 3931/ mobile: $+44(0) 7740421663$.

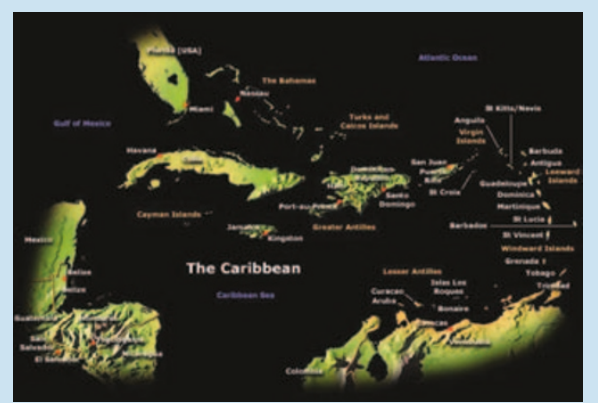




\section{Winning innovations gain funding}

August 2005

FDI World Dental Congress 2005

Date: 24-27.08.05

Venue: Palais de Congrès, Montréal

Email: congress@fdiworldental.org

www.fdiworldental.org

\section{September 2005}

Oral health through public health: Professor

Aubrey Sheiham, A Celebration of his work

Date: 5-6.09.05

Venue: University College London

www.ucl.ac.uk/dph

The Irish Endodontic Society 12th Biennial

Congress of the European Society of

Endodontology

Date: 15-17.09.05

Venue: Dublin

Tel: +35316799144

Fax: +35316486197

www.esedublin2005.com

\section{October 2005}

146th American Dental Association Annual Session and Technical Exhibition

Date: 6-9.10.05

Venue: Pennsylvania Convention Center, Philadelphia

Email: annualsession@ada.org

www.ada.org

British Dental Trade Association

International Dental Showcase 2005

Date: 6-8.10.05

Venue: NEC Birmingham

Tel: 08702413365

www.dentalshowcase.com

\section{DenTech China 2005}

Date: 26-29.10.05

Venue: Shanghai Everbright Convention \& Exhibition Center, Shanghai

Tel: 86-21-6294 6966

Fax: 86-21-6280 0908

Email:mail@showstar.net

www.dentech.com.cn

\section{November 2005}

2nd European Congress on the Reconstruction of the Periodontally Diseased Patient

Date: 25-27.11.05

Venue: Radisson SAS Scandinavia Hotel, Copenhagen

Email: kongress@quintessenz.de

www.quintessenz.de/ecrp

Greater New York Dental Meeting

Date: 25-30.11.05

Venue: New York

Email:info@gnydm.com

www.gnydm.com
An implant that can help fight tooth decay has won funding for Heriot-Watt University as part of Scottish Enterprise's 2005 Proof of Concept programme. The project, together with another that involves a novel way of transporting natural gas products in a semi-solid form has won $£ 321,000$ for the University.

The dental insert programme involves an implant that slowly releases anti-caries agents to strengthen teeth and reduce the number of bacteria causing tooth decay.

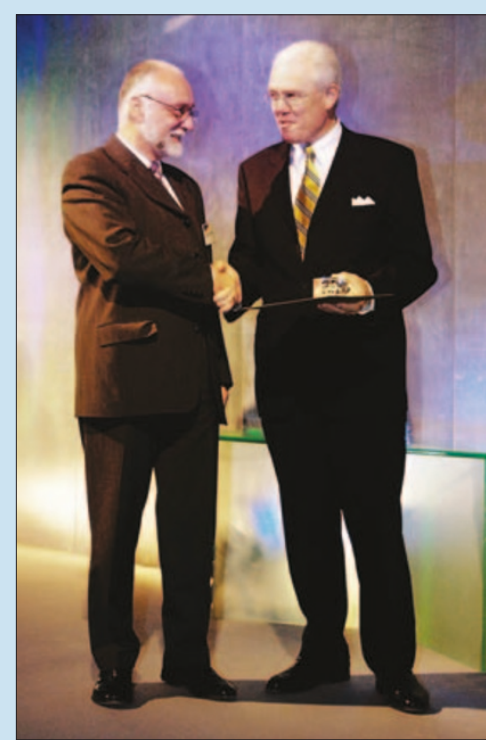

Dr Alex Fotheringham receiving the Proof of Concept Award from Jack Perry, Chief Executive of Scottish Enterprise.
It is intended that the insert, which will be biodegradable and would not therefore have to be removed from the patient once fitted, could also be used to release agents which treat conditions such as periodontal disease. Heriot-Watt is carrying out the project in partnership with Dundee University. Project leader Dr Alex Fotheringham said, "The value of this innovation lies in its potential to prevent dental caries, thereby reducing the number of fillings required and maintaining good dental health. This cost-effective device will save money for providers of dental health, allowing resources to be allocated to more demanding procedures."

The Proof of Concept Programme supports leading-edge technologies in Scotland's academic institutions, and aims to help export innovation from the lab into the global marketplace. It concentrates on early-stage ideas which have typically reached patent level and could lead to the creation of new businesses, or licensing innovative technologies. Successful bidders must demonstrate that their ideas have originality and true commercial potential.

\section{Wide variations in child dental health found}

A report into the state of pre-school children's dental health across the South East has found wide variations in dental health in the region. Published by the South East Public Health Observatory (SEPHO), the report looked at dental health in five-yearolds by analysing data from Primary Care Trusts (PCTs) and Strategic Health Authorities (SHAs) across the South East between 1995 and 2002. It found that dental health in young children had improved across the South East since 1995, and was above the national average but that there were wide variations between different areas, with some groups of children suffering significant levels of damaged teeth.

Kent and Medway SHA had the best record on dental health and met the 2003 national target for oral health in five-year-olds. The SHA had the lowest average number of decayed, missing or filled teeth in 2001-2002 while the areas of Thames Valley had the worst. Greater Manchester and West Yorkshire SHAs had the poorest dental health.

The report added that although fluoridation of water and other dental products are proven methods of preventing tooth decay, no areas of the South East have fluoridated water supplies. It also found a link between wealth and dental health, with the less affluent areas of the region having a worse record on dental health. Further work is taking place to investigate other reasons behind the inequalities highlighted by the report. Alison Hill, Director of SEPHO said, "This is the biggest study into the state of young children's teeth in the South East in recent years and it provides some valuable information for dentists and parents. Although the region as a whole compares well with others, we are concerned by the poor record on dental health in some parts of the region and by the reversal in improvements across the region in the last three years of the study."

The study recommended that PCTs should develop dental health strategies, identifying inequalities and developing targeted, preventive services and SEPHO is now working with public health dentists to urge the NHS and Local Authorities to address the issues raised by the report. This includes considering the fluoridation of public water supplies and the implementation of other prevention strategies in the areas with high levels of tooth decay. The report is available online at www.sepho.org.uk or by calling 01865334714 . 


\section{Birthday honours for dentists}

Four dentists received awards in the Queen's Birthday Honours List for 2005. Professor Anthony Blinkhorn, Professor of Oral Health, University of Manchester and Dr Norman Campbell Associate Specialist in Dental Surgery at Belfast City Hospital, were each appointed OBEs, while Dr Janice Fiske, Senior Lecturer and Consultant in Special Care Dentistry at the GKT Dental Institute and Dr Janet Griffiths, Associate Specialist, University Dental Hospital, Cardiff were each awarded MBEs. Dr John Armstrong Muir Gray CBE was knighted for services to the NHS.

Professor Anthony Blinkhorn was awarded an OBE for services to dentistry. His main clinical interest is the care of children with medical or physical handicaps and learning difficulties. Professor Blinkhorn developed services for such patients at the Royal Hospital for Sick Children in both Edinburgh and Glasgow and currently undertakes clinical services at St Mary's Children's Hospital, Royal Manchester Children's Hospital and the Dental Hospital.

Dr Norman Campbell has worked for many years with people with disabilities and was also recently awarded Honorary Life Membership of the British Society for Disability and Oral Health (BSDH). He is a past membership secretary for that Society as well as being a representative for the International Association for Disability and Oral Health (IADH).

Dr Janice Fiske was awarded an MBE for services to Special Care Dentistry (SCD). Janice has spent her career in paedodontics, gerodontics and SCD, is past president of BSDH and of the British Society of Gerodontology and is on the editorial boards of the Journal of Disability and Oral Health and Gerodontology. As chairperson of the Joint Advisory Committee in Special Care Dentistry she is involved in moving the development of a specialty in SCD onto the national agenda.

Dr Janet Griffiths is also well known in the field of SCD (a branch of dentistry heavily represented in this Honours List) in her native Wales. Having previously won awards and recognition for her work with the Special Interest Group in Wales, Janet is also well known in the Gwent area for setting up a charity with a bequest from her parents providing support services for adults with diasbilities.

Dr John Armstrong Muir Gray CBE was knighted for services to the NHS. He is Director of Knowledge Management and Programmes, UK National Screening Committee, and has been involved in promoting and developing evidence based dentistry.

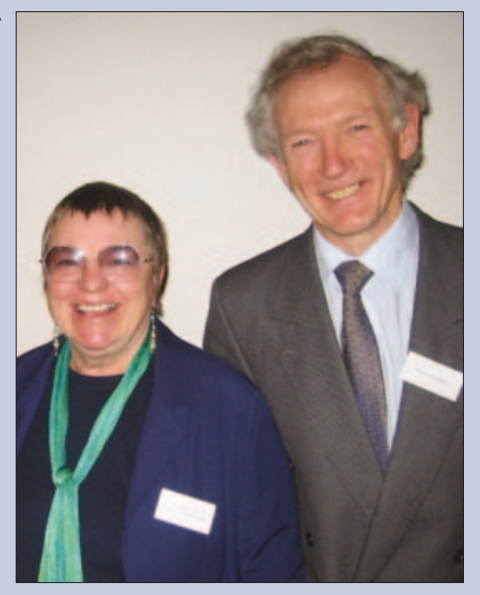

Dr Janet Griffiths and Dr Norman Campbell

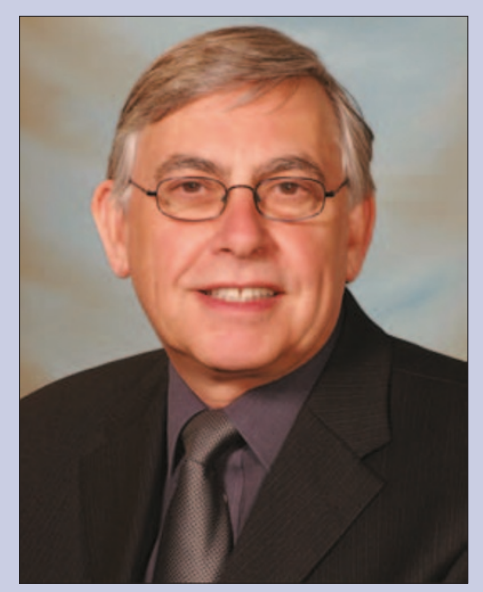

Professor Anthony Blinkhorn

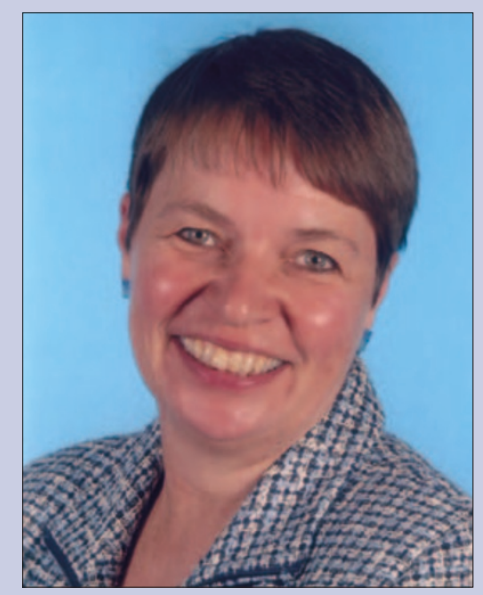

Dr Janice Fiske

\section{GDC agrees registration fees for 2006}

The General Dental Council has agreed new registration fee levels for 2006. Subject to Privy Council approval, the new levels will mean a registration and retention fee of $£ 409$, an increase of $£ 13$ (3.2\%) for dentists. The GDC claims that the increase, which is in line with inflation, will aim to help it deal with any unpredicted increases in demands and should avoid the need for sharper fee increases in the future.

It has also reconfirmed its position that fee discounts should not be introduced for particular groups of registrants, for example on the grounds of age or employment status.

\section{Charity status gained}

Yorkshire based group the Mouth Cancer Foundation has become the UK's first registered mouth cancer charity. The Mouth Cancer Foundation was established in June 2004 to be a professional support organisation solely dedicated to supporting people with mouth, throat and other head and neck cancers face the crisis of the illness. It gained charitable status (registered charity No. 110929) in May 2005. Dr Vinod K Joshi, Consultant in Restorative Dentistry at Pinderfields Hospital, Wakefield, and founder of the organisation, commented, "In the course of my work, I realised that my patients and their dentists needed easier access to information, as well as more comprehensive information, about oral care and advice before, during and after treatment for head-and-neck cancers and also about early detection, treatment and complications. It also became apparent that these patients needed a support group and there needed to be greater public awareness of mouth cancers." For more information visit www.mouthcancerfoundation.org.

\section{General Dental Council}

